\title{
GABA-B Agonist Baclofen Normalizes Auditory- Evoked Neural Oscillations and Behavioral Deficits in the Fmr1 Knockout Mouse Model of Fragile X Syndrome
}

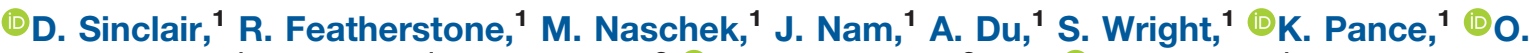 \\ Melnychenko, ${ }^{1}$ R. Weger, ${ }^{1}$ S. Akuzawa, ${ }^{2}{ }^{-M}$. Matsumoto, ${ }^{2}$ and ${ }^{\circ}$ S. J. Siegel ${ }^{1}$
}

DOI:http://dx.doi.org/10.1523/ENEURO.0380-16.2017

${ }^{1}$ Translational Neuroscience Program Department of Psychiatry, University of Pennsylvania, Philadelphia, PA 19104, USA, and ${ }^{2}$ Neuroscience Research Unit, DDR, Astellas Pharma Inc., Tsukuba-Shi, Ibaraki 305-8585, Japan

\begin{abstract}
Fragile $\mathrm{X}$ syndrome is a genetic condition resulting from FMR1 gene mutation that leads to intellectual disability, autism-like symptoms, and sensory hypersensitivity. Arbaclofen, a GABA-B agonist, has shown efficacy in some individuals with FXS but has become unavailable after unsuccessful clinical trials, prompting interest in publicly available, racemic baclofen. The present study investigated whether racemic baclofen can remediate abnormalities of neural circuit function, sensory processing, and behavior in Fmr1 knockout mice, a rodent model of fragile X syndrome. Fmr1 knockout mice showed increased baseline and auditory-evoked high-frequency gamma $(30-80 \mathrm{~Hz})$ power relative to C57BL/6 controls, as measured by electroencephalography. These deficits were accompanied by decreased T maze spontaneous alternation, decreased social interactions, and increased open field center time, suggestive of diminished working memory, sociability, and anxiety-like behavior, respectively. Abnormal auditoryevoked gamma oscillations, working memory, and anxiety-related behavior were normalized by treatment with baclofen, but impaired sociability was not. Improvements in working memory were evident predominantly in mice whose auditory-evoked gamma oscillations were dampened by baclofen. These findings suggest that racemic baclofen may be useful for targeting sensory and cognitive disturbances in fragile $\mathrm{X}$ syndrome.
\end{abstract}

Key words: EEG; fragile X syndrome; GABA; gamma; racemic baclofen; working memory

\section{Significance Statement}

Baclofen stimulates the inhibitory GABA-B receptor and is the publicly available version of arbaclofen, a candidate drug for fragile $X$ syndrome that showed initial promise in clinical trials but did not succeed overall and is now unavailable. Using the Fmr1 knockout mouse model of fragile $\mathrm{X}$ syndrome, we show that baclofen may have potential for targeting abnormal sensory sensitivity (in the form of increased auditoryevoked high-frequency neural oscillations) and cognitive deficits (particularly spatial working memory) in fragile $X$ syndrome. This work also highlights the possible usefulness of electroencephalography, which measures neural oscillations, for predicting treatment responsiveness in select fragile $\mathrm{X}$ symptom domains.

\section{Introduction}

Fragile $X$ syndrome (FXS) is a debilitating neurodevelopmental disorder that results from mutation of the FMR1

Received December 20, 2016; accepted February 13, 2017; First published February 17, 2017.

SJS is a consultant to, and receives grant support from, Astellas Pharma gene (Verkerk et al. 1991) and loss of fragile $X$ mental retardation protein (FMRP). It affects $\sim 1$ in 4000 males and 1 in 8000 females (Turner et al. 1996) and is charac- 
terized by cognitive deficits, hyperactivity, attention problems, social communication deficits, and increased anxiety (Bailey et al. 2008). Approximately $40 \%$ of individuals with FXS display symptoms of autism spectrum disorder (ASD; Bailey et al. 2008). Treatment options for FXS are currently limited and have historically focused on symptoms such as anxiety (Bailey et al. 2012). More recently, evidence-based FXS pharmacotherapies (Healy et al. 2011; Lozano et al. 2014) have emerged. Some such therapies have targeted the $\gamma$-aminobutyric acid (GABA) neurotransmitter signaling pathway, based on evidence of GABAergic deficits in Fmr1 knockout (KO) mice (Gantois et al. 2006; Adusei et al. 2010; Paluszkiewicz et al. 2011), a rodent model with strong construct validity for FXS.

The GABA-B agonist arbaclofen (STX209) has shown promise preclinically, rescuing behavioral abnormalities in Fmr1 KO mice (Henderson et al. 2012; Qin et al. 2015) and mouse models of ASD (Silverman et al. 2015). Studies on the effects of arbaclofen in individual with FXS have shown mixed results (Lozano et al. 2014). In adults and children with FXS, arbaclofen did not improve overall symptom severity (Berry-Kravis et al. 2012). However, improvement in select symptom domains was seen in some individuals, consistent with anecdotal evidence of efficacy provided by families of individuals with FXS (Lozano et al. 2014). In the face of these results, arbaclofen trials in FXS were ceased in May 2015, and the drug was made unavailable for clinical research.

The overall failure of arbaclofen in human FXS trials may have occurred because arbaclofen is beneficial for only a subset of individuals or is effective for only a limited subset of symptoms. Furthermore, although arbaclofen is currently unavailable for research or treatment, racemic baclofen is available and may be used off-label for FXS. As a result, it is critical to establish the usefulness of racemic baclofen for treating key FXS symptom domains and behaviors.

Author contributions: D.S., R.F., S.A., M.M., and S.J.S. designed research; D.S., R.F., M.N., J.N., A.D., S.W., K.P., O.M., and R.W. performed research; D.S., R.F., M.N., J.N., A.D., S.W., K.P., O.M., R.W., and S.J.S. analyzed data; D.S., R.F., and S.J.S. wrote the paper.

Department of Health I National Health and Medical Research Council (NHMRC) [APP1072878]; Astellas Pharma (Astellas).

D. Sinclair's present address: Wicking Centre, University of Tasmania, Private Bag 143, Hobart, TAS 7001, Australia; R. Featherstone's present address: Department of Psychiatry and Behavioral Science, University of Southern California, Los Angeles, CA 90033; O. Melnychenko's present address: Department of Psychiatry and Behavioral Science, University of Southern California, Los Angeles, CA 90033; S. J. Siegel's present address: Department of Psychiatry and Behavioral Science, University of Southern California, Los Angeles, CA 90033.

Acknowledgments: We thank A/Prof. Tim Karl and Don Brown for advice. Correspondence should be addressed to either of the following: Steven J Siegel, Department of Psychiatry and Behavioral Science, University of Southern California, 2250 Alcazar St, Ste 2200, Los Angeles, CA 90033. E-mail: siegels@usc.edu; or Duncan Sinclair, Wicking Centre, University of Tasmania, Private Bag 143, Hobart, TAS 7001, Australia. E-mail: duncan.sinclair@utas.edu.au.

DOI:http://dx.doi.org/10.1523/ENEURO.0380-16.2017

Copyright (C) 2017 Sinclair et al.

This is an open-access article distributed under the terms of the Creative Commons Attribution 4.0 International, which permits unrestricted use, distribution and reproduction in any medium provided that the original work is properly attributed.
Sensory abnormalities are key symptoms of FXS and ASD (Sinclair et al. 2016) that may differentiate individual responses to baclofen. Sensory abnormalities can be objectively assessed using electroencephalography (EEG) in both humans with FXS and Fmr1 KO mice. Humans with FXS show evidence of auditory hypersensitivity, disrupted preattentive stimulus recognition, and altered novelty detection by EEG (St Clair et al. 1987; Castrén et al. 2003; Van der Molen et al. 2012a, b; Ethridge et al. 2016), as do Fmr1 KO mice (Chen and Toth, 2001; Frankland et al. 2004; Gibson et al. 2008; Lovelace et al. 2016). Because abnormalities of sensory processing are likely to contribute to sensory hypersensitivity and other deficits in FXS, they are an important potential target for baclofen treatment.

Therefore, we had three primary aims. First, we set out to determine the extent of sensory processing abnormalities in Fmr1 KO mice, particularly at the level of in vivo neural oscillations. Although EEG has been used previously in Fmr1 KO mice (Gonçalves et al. 2013; Radwan et al. 2016), to our knowledge auditory-evoked oscillations have not been investigated. Second, we explored whether EEG oscillation abnormalities and behavioral deficits in Fmr1 KO mice could be rescued by acute racemic baclofen treatment. Fmr1 KO mice show abnormal locomotor activity, anxiety-like behavior, reduced social interactions, and impaired working memory (Bakker et al. 1994; Kramvis et al. 2013; Hébert et al. 2014; Oddi et al. 2015), but the amenability of these deficits to racemic baclofen treatment is unclear (Pacey et al. 2009). Finally, we investigated whether rescue of specific EEG oscillation abnormalities at an individual level was associated with improvement in behavior or cognition, as a proof of concept for the possible future use of EEG to predict treatment responsiveness in individuals with FXS.

\section{Materials and Methods}

\section{Study design}

This study compared inbred adult Fmr1 KO mice to wild-type (WT) controls using a within-subject design, testing the hypothesis that sensory hypersensitivity in Fmr1 KO mice would be reflected in abnormal stimulusevoked neural activity and would relate to behavioral deficits. Neural oscillations (at baseline and in response to auditory stimulus), open-field behavior, social interactions, spatial working memory, and spatial episodic memory were quantified sequentially in the same mice. Each test was conducted on four separate days. Vehicle was administered on test day 1 , then $1 \mathrm{mg} / \mathrm{kg}$ baclofen on test day $2,2.5 \mathrm{mg} / \mathrm{kg}$ baclofen on test day 3 and $5 \mathrm{mg} / \mathrm{kg}$ baclofen on test day 4 , with $48 \mathrm{~h}$ washout between test days. Based on previous experience of the sample size required to reveal biologically relevant differences in EEG and behavior (Gandal et al. 2012a, b; Billingslea et al. 2014; Tatard-Leitman et al. 2015), 15-23 mice per genotype and sex were used.

\section{Animals and drug preparation}

Homozygous female Fmr1 KO mice and hemizygous male Fmr1 KO mice on a C57BL/6 background (strain 


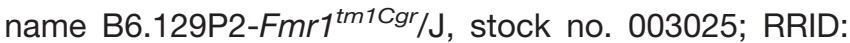
MGl:4950026; Bakker et al. 1994), along with WT C57BL/6 controls, were received from The Jackson Laboratory at $28 \mathrm{~d}$ of age. Littermates did not serve as WT controls, since the required breeding strategy for homozygous female Fmr1 KO mice does not generate WT mice. Animals were group-housed in standard cages (Allentown Inc.) with food and water ad libitum, in a room maintained on a $12 \mathrm{~h}$ light-dark cycle. Mice were habituated to the colony environment for 4 weeks before electrode implantation and underwent surgery at postnatal day $\sim 56$. Animals were singly housed for the remainder of the study to prevent postoperative complications. All protocols for animal care and use were undertaken in accordance with University Laboratory Animal Resources and NIH guidelines and were approved by the Institutional Animal Care and Use Committee (University of Pennsylvania protocol \#803572). Racemic baclofen (cat. \#5399; Sigma-Aldrich) was dissolved in $0.9 \%$ saline immediately before use and administered intraperitoneally at $1,2.5$, or $5 \mathrm{mg} / \mathrm{kg}$ in $100 \mu \mathrm{l}$ injection volume. Testing was conducted $5 \mathrm{~min}$ after injection.

\section{Electroencephalography}

Animals were anaesthetized with isoflurane and implanted unilaterally with a tripolar electrode assembly. The recording electrode was placed $1.8 \mathrm{~mm}$ posterior, 2.65 $\mathrm{mm}$ right lateral, and $2.75 \mathrm{~mm}$ deep relative to Bregma to detect changes in the electrical field emanating from the hippocampus and cortex. Reference and ground electrodes were placed transversely onto the surface of the ipsilateral neocortex, $0.8 \mathrm{~mm}$ deep (Featherstone et al. 2015). Electrodes were secured to the skull with ethyl cyanoacrylate and dental cement. Mice were allowed a 10 d period of recovery before testing. Neural oscillations were recorded within a Faraday cage using a highimpedance differential AC amplifier (model \#1800, A-M Systems) and Spike 2 software (Cambridge Electronic Design). Baseline oscillations were recorded in the first minute of the session, 5 min after IP injection. Thereafter, 120 broadband white-noise stimuli $(10 \mathrm{~ms}$ duration, $85 \mathrm{~dB}$ with an $8 \mathrm{~s}$ interstimulus interval) were administered. Raw EEG was filtered between 1 and $500 \mathrm{~Hz}$, and individual sweeps were rejected for movement artifact based on a criterion of $2 \times$ root mean squared amplitude per mouse. For event-related potentials (ERPs), the P20 peak was defined as the largest positive voltage deflection between 15 and $30 \mathrm{~ms}$ and the N40 peak as the largest negative voltage deflection between 30 and $100 \mathrm{~ms}$. Baseline power was derived by fast Fourier transformation (FFT) using the FFT function native to Spike2. Baseline absolute gamma power was quantified as the average gamma power $(30-80 \mathrm{~Hz})$ across the $60 \mathrm{~s}$ prestimulus period. Baseline relative gamma power was expressed as the proportion of gamma power $(30-80 \mathrm{~Hz})$ relative to total power $(0-120 \mathrm{~Hz})$. Event-related power from 0 to $200 \mathrm{~ms}$ after stimulus was baseline-corrected and derived using time-frequency decomposition methods native to the EEGLAB toolbox (Delorme and Makeig, 2004; RRID: SCR_007292) within Matlab (Mathworks; RRID: SCR_001622) as previously described (Billingslea et al. 2014; Tatard-Leitman et al. 2015).

\section{Behavioral tests}

Behavioral testing was performed with $F m r 1 \mathrm{KO}$ and WT mice at 6-10 weeks of age. Testing took place during the light phase. Each test was repeated on four separate sessions for administration of vehicle or $1,2.5$, or $5 \mathrm{mg} / \mathrm{kg}$ baclofen, with a $48 \mathrm{~h}$ washout between sessions. There was a break of 4-5 days between each behavioral test. The chronological order of tests was open field, continuous T-maze, three-chamber social interaction, and modified radial water maze.

For the open-field test, mice acclimated in the testing room for $15 \mathrm{~min}$ before recording. Five minutes after IP injection with saline or baclofen, mice were placed in a clear Perspex open-field recording chamber $(40 \times 40 \mathrm{~cm})$ divided into a $16 \times 16$ photobeam grid (Photobeam Activity System, San Diego Instruments). Locomotor activity (the number of photobeam breaks in $10 \mathrm{~min}$ ), time spent in the center of the chamber (central area, $15 \times 15 \mathrm{~cm}$ ), and time spent in the periphery (peripheral area, $25 \mathrm{~cm}$ zone flanking chamber walls) were the measures of interest, quantified using Photobeam Activity System software (San Diego Instruments). Two mice at $5 \mathrm{mg} / \mathrm{kg}$ baclofen (one female WT and one female KO) were omitted because of technical problems recording the test.

The apparatus used for assessing social interaction consisted of two interaction chambers $(19 \mathrm{~cm}$ wide, 26 $\mathrm{cm}$ deep, and $22 \mathrm{~cm}$ tall), each containing a wire mesh cylinder (8 cm in diameter, $12 \mathrm{~cm}$ tall) as previously described (Sankoorikal et al. 2006; Ehrlichman et al. 2009). The interaction chambers were separated by a central chamber ( $13 \mathrm{~cm}$ wide, $26 \mathrm{~cm}$ deep, and $22 \mathrm{~cm}$ tall). The walls between chambers had an opening $11 \mathrm{~cm}$ wide. The testing room was maintained under dim light. At the start of the test the mesh cylinders were empty, and test mice were placed in the apparatus to habituate for $10 \mathrm{~min}$. Mice were then injected with saline or baclofen and returned to their home cages for $5 \mathrm{~min}$. For the interaction test, a female $A / J$ stimulus mouse was placed in one mesh cylinder and an inanimate object (tennis ball) was placed in the other. Test mice were then reintroduced into the testing apparatus and the experimenter left the room. Social interaction was quantified as the number of sniffing bouts at the mesh cylinder containing the stimulus mouse (social) versus the inanimate object (nonsocial). The number of social and nonsocial interactions was scored manually and expressed as a percentage of the total number of interactions. Seven mice (three female WT and four male WT) were assessed in the vehicle condition but not included in further analyses because of technical difficulties with recording during one baclofen test session.

Working memory was assessed using the spontaneous alternation T-maze. Mice were acclimated in white light in a room adjacent to the testing room for $15 \mathrm{~min}$ before recording. Five minutes after injection of saline or baclofen, mice were placed at the end of the central arm of an opaque plastic T-maze (arm dimensions $30 \mathrm{~cm}$ long, 
$10 \mathrm{~cm}$ wide, and $12 \mathrm{~cm}$ tall), which contained $1 \mathrm{~cm}$ of fresh bedding. Navigation of the mouse in the maze was recorded for 5 min with a Sony NightShot digital camera. Arm entries were scored manually, with an entry recorded if the mouse progressed more than halfway into the arm and a correct alternation recorded if the entry occurred in the most novel (least recently visited) arm. The number of correct entries, as a percentage of total entries during the 5 min test, was scored manually. One male WT mouse was assessed in the vehicle but did not complete the test at $1 \mathrm{mg} / \mathrm{kg}$ baclofen and was excluded. Testing took place in a dimly lit room.

Finally, episodic memory was assessed on a modified radial water maze task. The apparatus consisted of four transparent plastic arms (arm dimensions $30 \mathrm{~cm}$ long, 10 $\mathrm{cm}$ wide, and $24 \mathrm{~cm}$ tall), with a $20 \mathrm{~cm}$ square central zone contained in a room under white light with distal visual cues (wall posters). The maze was filled to a depth of $1 \mathrm{~cm}$ with an opaque mixture of room temperature water and white tempura paint. This depth of water was sufficient to motivate the mice to find the platform and also to hide the platform. At the end of one arm, a white platform was placed level with the water surface. Mice were trained for three consecutive days, and on each day were given five trials (training trials) to locate the platform. Mice were gently shepherded to the platform if they were unable to locate the platform after $60 \mathrm{~s}$. Mice were dried and allowed to recuperate for $15 \mathrm{~min}$ on a heated home cagelike enclosure between trials. On each sequential trial, the arm in which the mouse started the test was varied. Test days commenced $48 \mathrm{~h}$ after the last training day. Each mouse was habituated to the testing room for $10 \mathrm{~min}$, injected IP with saline or baclofen in its home cage, and commenced testing (test trials) 5 min later. Mice were tested in each arm in random order, and the latency to find the platform recorded manually. The latency across the three test trials was averaged. Three mice (one female $\mathrm{WT}$, one male WT, one male $\mathrm{KO}$ ) did not complete the test on one of the baclofen testing days and were included in the vehicle, but not baclofen, analysis.

\section{Statistical analysis}

Data from each test were approximately normally distributed (skewness between -1 and 1 ) with the exception of open field percentage center time and radial water maze latency, for which all data were log transformed to achieve normality. Analyses were conducted in two stages. First, analyses of genotype and sex differences were performed in the vehicle condition using factorial ANOVA. Second, main effects of genotype, sex, and baclofen dose (within-subject factor) were assessed across baclofen conditions using repeated-measures ANOVA. Post hoc comparisons were performed using the least-significant difference test when significant main effects or interactions were found. Correlations between continuous variables were investigated using Pearson's correlations. No outliers were removed. All analyses were performed using Statistica (Dell Inc.; RRID: SCR_014213).

\section{Results}

\section{Effects of Fmr1 KO and baclofen on ERP measures P20}

Amplitude of the P20 did not differ between Fmr1 KO and WT mice $(p=0.26$; Fig. $1 A, C, F)$ nor between male and female mice $(p=0.45$; Fig. $1 F)$ in the vehicle condition. Baclofen increased P20 amplitude at all doses $\left[F_{(3,204)}=8.30, p=0.00003\right.$; Fig. $\left.1 B, D-F\right]$, with the greatest effect at $2.5 \mathrm{mg} / \mathrm{kg}$. Across baclofen doses, P20 amplitude did not differ across genotypes or sexes $(p=$ 0.31 and $p=0.98$ respectively; Fig. $1 F)$. The effect of baclofen on P20 amplitude did not differ between Fmr1 $\mathrm{KO}$ and WT mice (genotype $\times$ drug interaction, $p=0.11$ ) but was larger in female than male mice [sex $\times$ drug interaction, $F_{(3,204)}=3.14, p=0.026$; Fig. $1 F$.

\section{N40}

A similar pattern was observed with $\mathrm{N} 40$ amplitude, with no significant main effects of genotype or sex with vehicle (genotype, $p=0.86$; sex, $p=0.51$; Fig. $1 A, C, G$ ) or during baclofen treatment (genotype, $p=0.11$; sex, $p$ $=0.30$; Fig. $1 B, D, G)$. There was a significant main effect of baclofen $\left[F_{(3,204)}=11.75, p<0.000001\right.$; Fig. $\left.1 E, G\right]$. $\mathrm{N} 40$ amplitude was increased at $1 \mathrm{mg} / \mathrm{kg}(p=0.001)$ and $2.5 \mathrm{mg} / \mathrm{kg}(p=0.000002)$ baclofen relative to vehicle, but not at $5 \mathrm{mg}(p=0.53)$. The effect of baclofen on N40 amplitude did not differ between Fmr1 KO and WT mice (genotype $\times$ drug interaction, $p=0.07$ ) or between female and male mice (drug $\times$ sex interaction, $p=0.23$ ).

\section{Effects of Fmr1 KO and baclofen on high-frequency neural oscillations \\ Baseline power}

The absolute power of gamma $(30-80 \mathrm{~Hz})$ frequency neural oscillations (Fig. 2A, $B, E-I)$, and the relative power of gamma oscillations [as a proportion of total $(0-120 \mathrm{~Hz})$ power; Fig. $2 C, D, J$ were quantified, because oscillations at this frequency are thought to relate to cognitive function (Salinas and Sejnowski, 2001; Buzsáki and Wang, 2012) as well as being driven by the activity of GABAergic interneurons (Buzsáki and Wang, 2012) that are implicated in FXS (Adusei et al. 2010; Paluszkiewicz et al. 2011). For baseline absolute gamma power in the vehicle condition, there was greater power in Fmr1 KO than in WT mice overall $\left[F_{(1,68)}=11.73, p=0.001\right.$; Fig. 2]]. This genotype difference was present in males $(p=0.00002$; Fig. $2 /)$ but not in females $(p=0.61)$ [genotype $\times$ sex interaction: $\left.F_{(1,68)}=7.07, p=0.013\right]$. Across all baclofen doses, the overall genotype difference was still evident $\left[F_{(1,68)}=11.34, p=0.001\right]$. Again, this genotype difference trended toward a significant difference in males $p=$ 0.0001 ; Fig. $2 /$ ) but not females $[p=0.35$; genotype $\times$ sex interaction, $\left.F_{(1,68)}=3.85, p=0.054\right]$. In the vehicle condition, there was greater baseline absolute gamma power in females than males $\left[F_{(1,68)}=6.44, p=0.013\right]$, driven by sex differences in WT mice ( $p=0.00002$; Fig. $2 /)$ but not Fmr1 KO mice $(p=0.93)$ owing to the genotype $\times$ sex interaction. There was no effect of baclofen on baseline absolute gamma power $(p=0.76$; Fig. $2 /)$. 

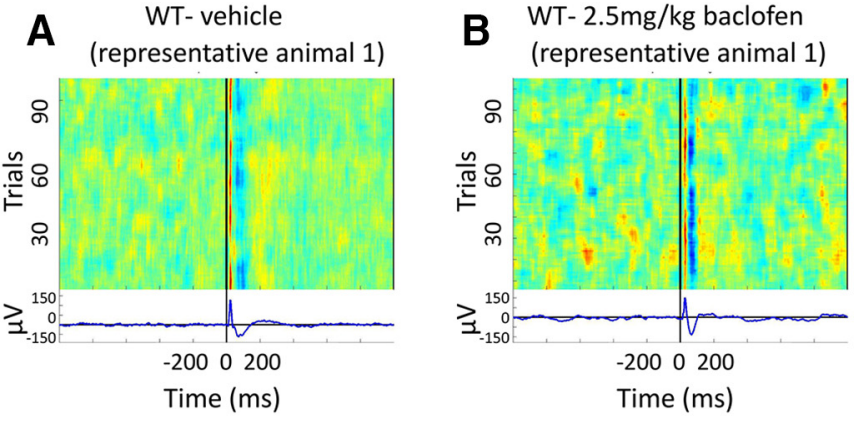
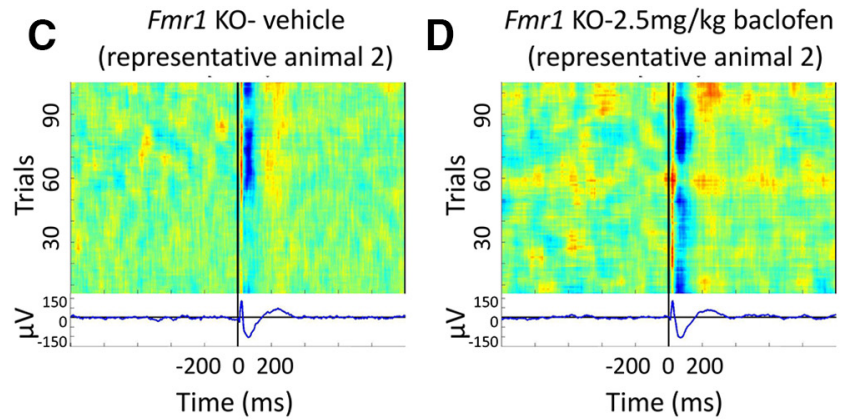

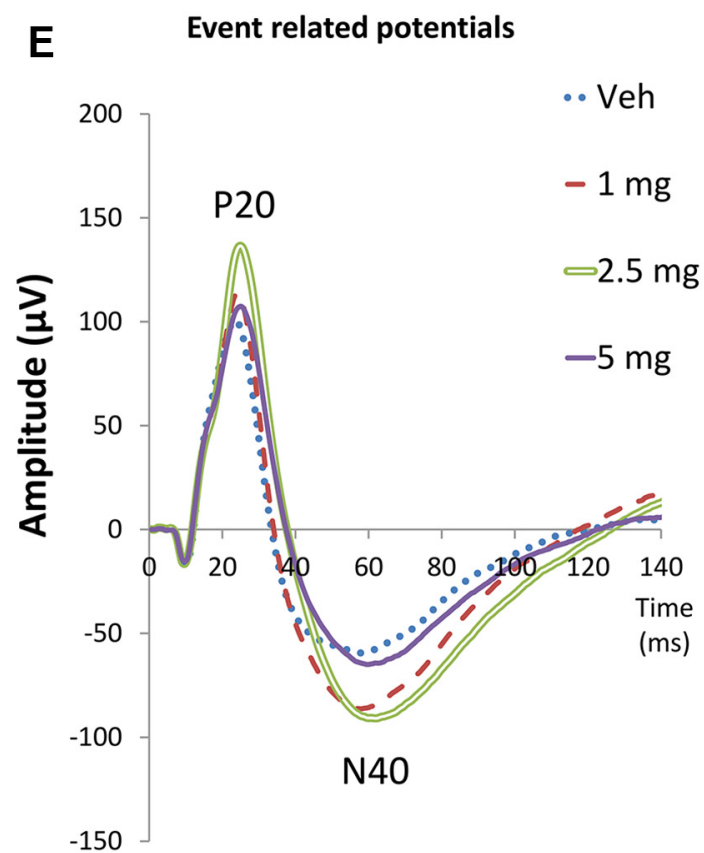

F

G
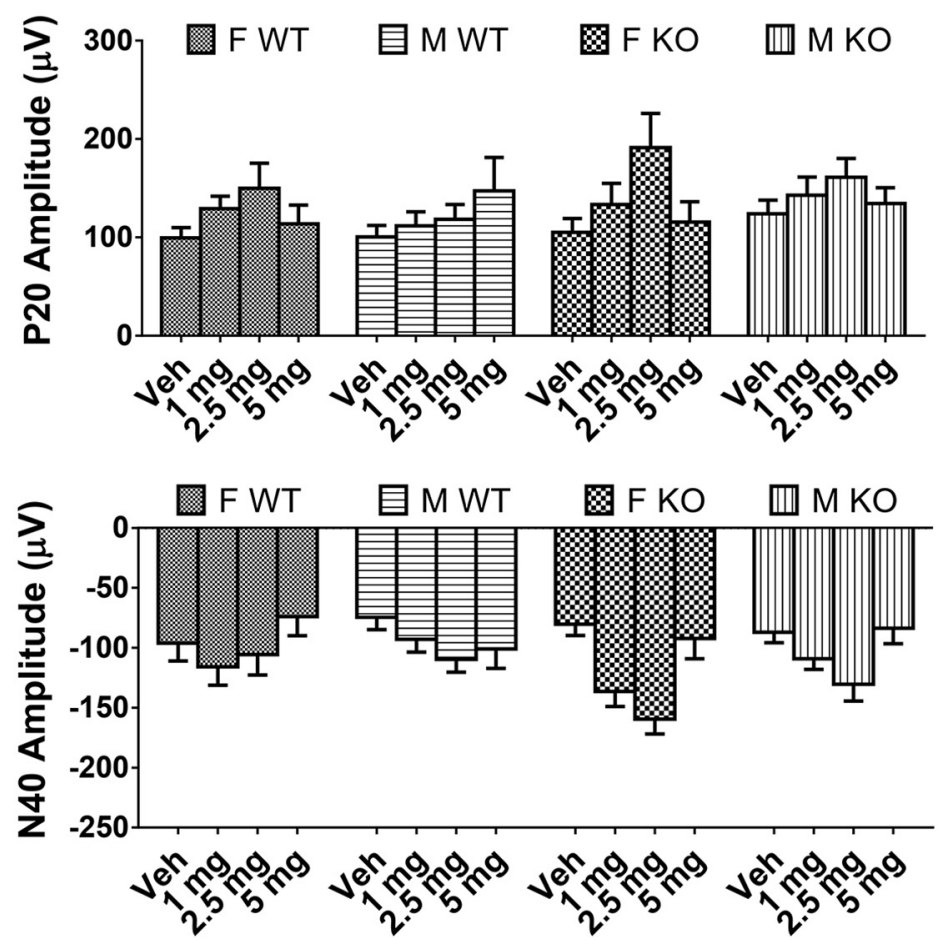

Figure 1. Effects of baclofen on ERPs in Fmr1 KO and WT mice (F-WT, $n=16$; F-KO, $n=15 ; \mathrm{M}-\mathrm{WT}, n=23 ; \mathrm{M}-\mathrm{KO}, n=18)$. A-D, Heat maps and traces showing positive and negative ERP deflections across test trials from representative WT (A, B) and Fmr1 KO $(\boldsymbol{C}, \boldsymbol{D})$ mice after vehicle and $2.5 \mathrm{mg} / \mathrm{kg}$ baclofen administration. $\boldsymbol{E}$, Grand average waveforms with characteristic ERP deflections in all mice (female and male Fmr1 KO and WT) after vehicle or 1, 2.5, and $5 \mathrm{mg} / \mathrm{kg}$ baclofen. $\boldsymbol{F}$, Effects of baclofen on amplitudes of the P20 component of the ERP in female and male Fmr1 KO and WT mice. G, Effects of baclofen on amplitudes of the N40 ERP component. F, female, M, male, Veh, vehicle. Error bars represent SEM.

For baseline relative gamma power after vehicle, there was also greater power in Fmr1 KO mice than in WT mice $\left[F_{(1,68)}=10.99, p=0.001 ;\right.$ Fig. $\left.2 \mathrm{~J}\right]$ and a trend toward a significant genotype sex interaction $\left[F_{(1,68)}=\right.$ $3.89, p=0.053]$ with an effect of genotype in males ( $p$ $=0.0002$; Fig. $2 J$ ) but not females $(p=0.38)$. This genotype effect held across baclofen treatment conditions $\left[F_{(1,68)}=37.06, p<0.000001\right]$, and as seen in vehicle, male Fmr1 KO mice had greater elevations of relative baseline gamma power compared with WT than females [genotype $\times$ sex interaction, $F_{(1,68)}=9.23, p=$ 0.003; Fig. 2J]. In contrast to absolute gamma power, there was no overall sex difference (vehicle, $p=0.56$; baclofen, $p=0.26$ ). Baseline relative gamma power was strongly decreased by baclofen $\left[F_{(3,204)}=27.21\right.$, $p<0.000001$; Fig. 2J].

\section{Auditory stimulus-related power}

Changes to gamma power in response to auditory stimuli were also investigated (Fig. $2 K-N$ ). In the vehicle condition, the absolute power of evoked gamma oscillations, which are time-locked to the stimulus, did not differ between genotypes ( $p=0.15$; Fig. 2O). However, across all baclofen treatment groups together, evoked gamma power was significantly increased in $F m r 1 \mathrm{KO}$ mice compared with WT mice $\left[F_{(1,68)}=5.28, p=0.025\right.$; Fig. 2O]. There were no sex differences in evoked gamma power (vehicle, $p=0.39$; baclofen, $p=0.88$ ). A significant decrease in evoked gamma power was observed after baclofen $\left[F_{(3,204)}=13.96, \mathrm{p}<0.000001\right.$; Fig. $2 K-N$, O], which was strongest at $5 \mathrm{mg} / \mathrm{kg}(p=0.000003)$ relative to vehicle. A marginal effect was also observed at $2.5 \mathrm{mg} / \mathrm{kg}$ $(p=0.054)$. Baclofen had the same effect in WT and Fmr1 

A
All animals
B All animals
(Veh, $5 \mathrm{mg} / \mathrm{kg} \mathrm{Bac)}$
C All animals
D
All animals
(WT, KO)
(WT, KO)
(Veh, 5mg/kg Bac)

- Baseline absolute power spectra--_.
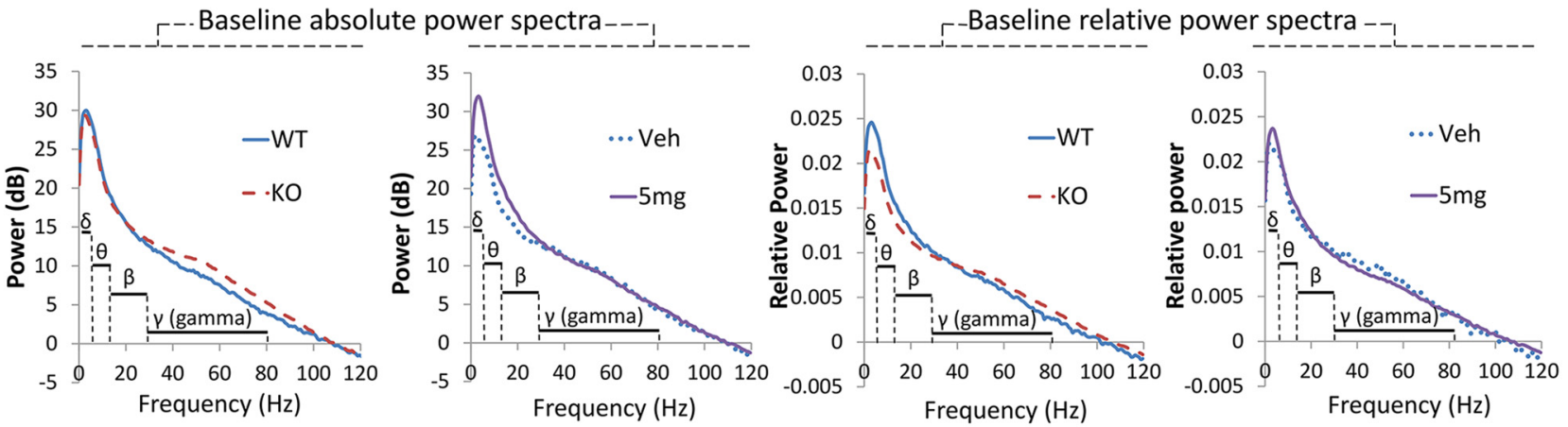

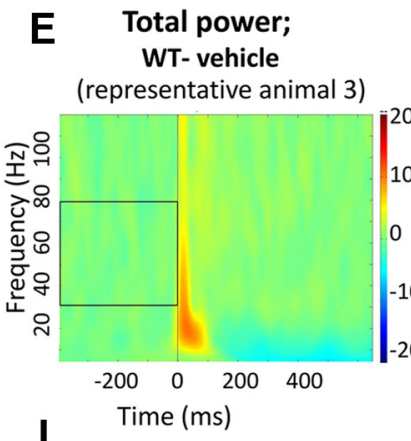

F Total power; WT- $2.5 \mathrm{mg} / \mathrm{kg}$ baclofen (representative animal 3)
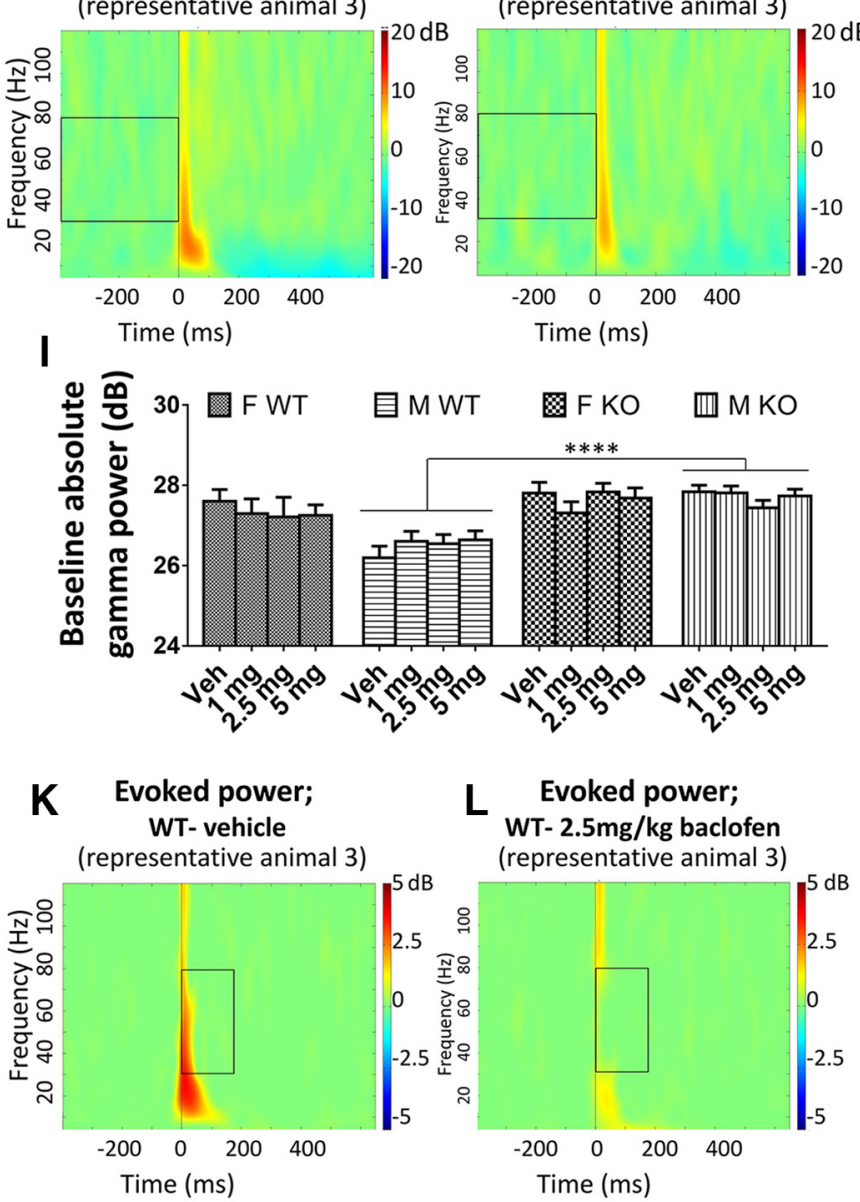

L Evoked power; WT- $2.5 \mathrm{mg} / \mathrm{kg}$ baclofen (representative animal 3)
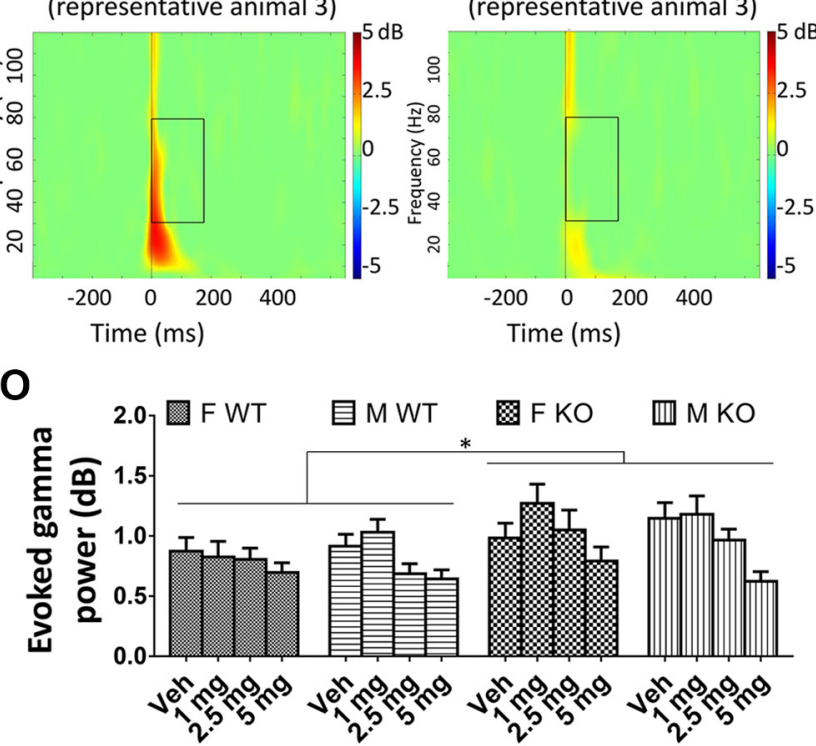

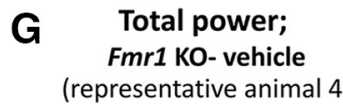

H Total power; Fmr1 KO- $2.5 \mathrm{mg} / \mathrm{kg}$ baclofen (representative animal 4)

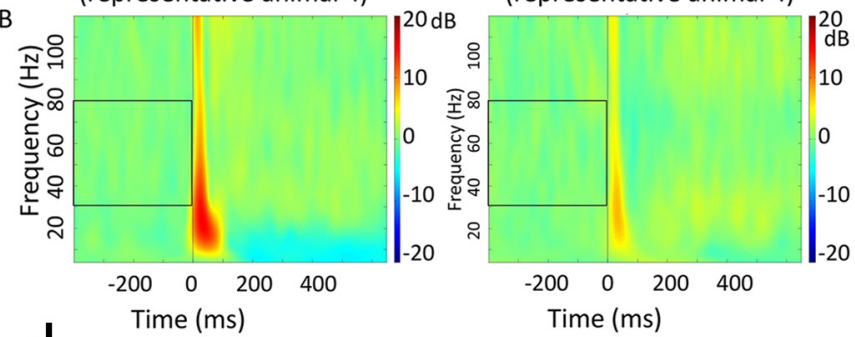

$J$

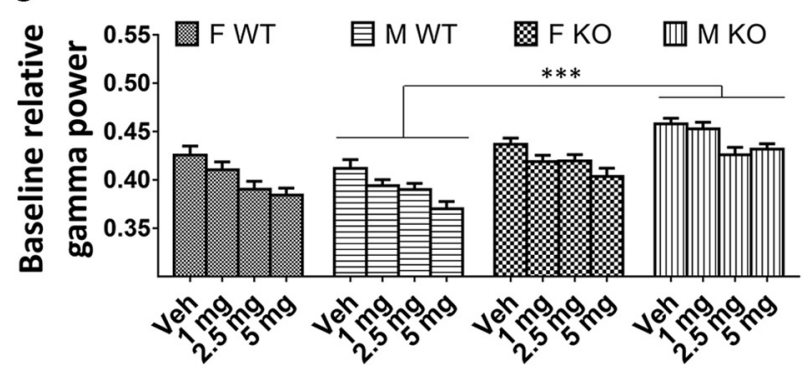

Evoked power;
Fmr1 KO- vehicle N Evoked power;

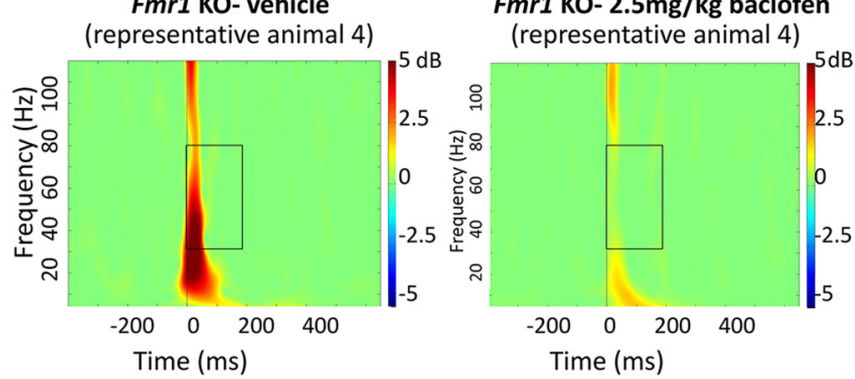

$\mathbf{P}$

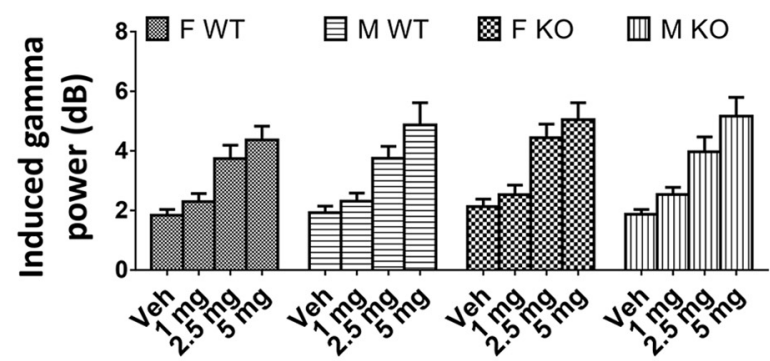

Figure 2. Effects of baclofen on baseline and auditory stimulus-related gamma oscillations in Fmr1 KO and WT mice (F-WT, $n=16$; 
continued

F-KO, $n=15 ; \mathrm{M}-\mathrm{WT}, n=23 ; \mathrm{M}-\mathrm{KO}, n=18)$. $\boldsymbol{A}, \boldsymbol{B}$, Baseline absolute power spectra in Fmr1 KO and WT mice $(\boldsymbol{A})$, and vehicle and $5 \mathrm{mg} / \mathrm{kg}$ baclofen treatment conditions $(\boldsymbol{B})$. $\boldsymbol{C}, \boldsymbol{D}$, Baseline relative power spectra (normalized to total 0 to $120 \mathrm{~Hz}$ power). $\boldsymbol{E}-\boldsymbol{H}, \mathrm{Heat}$ maps showing total power of EEG oscillations at baseline across 2 to $120 \mathrm{~Hz}$ frequencies from representative WT (E, $\boldsymbol{F})$ and $F m r 1 \mathrm{KO}$ $(\boldsymbol{G}, \boldsymbol{H})$ mice after vehicle and $2.5 \mathrm{mg} / \mathrm{kg}$ baclofen administration. Boxes highlight baseline gamma oscillations. I, Baseline absolute gamma power. $\boldsymbol{J}$, Baseline relative gamma power. $\boldsymbol{K}-\boldsymbol{N}$, Heat maps showing evoked power of EEG oscillations after stimulus across 2 to $120 \mathrm{~Hz}$ frequencies from representative WT $(\boldsymbol{K}, \boldsymbol{L})$ and $F m r 1 \mathrm{KO}(\boldsymbol{M}, \boldsymbol{N})$ mice after vehicle and $2.5 \mathrm{mg} / \mathrm{kg}$ baclofen administration. Boxes highlight auditory-evoked gamma oscillations. $\boldsymbol{O}$, Evoked gamma power. $\boldsymbol{P}$, Induced gamma power. F, female, M, male, Veh, vehicle. Error bars represent SEM. $* p<0.05, * * * p<0.0005, * * * * p<0.00005$

KO mice (genotype $\times$ drug interaction, $p=0.17$ ) and across sexes (sex $\times$ drug interaction, $p=0.21$; Fig. 2O). The power of induced gamma oscillations, which are not time-locked to the stimulus, was not influenced by genotype (vehicle, $p=0.59$; baclofen, $p=0.35$; Fig. $2 P$ ) or sex (vehicle, $p=0.69$; baclofen, $p=0.99$ ). However, induced gamma power was strongly increased by baclofen at all doses $\left[F_{(3,204)}=73.59, p<0.000001\right.$; Fig. $\left.2 P\right]$. This effect was equivalent in Fmr1 KO and WT mice (genotype $\times$ drug interaction, $p=0.81$ ) and female and male mice (sex $\times$ drug interaction, $p=0.67$ ).
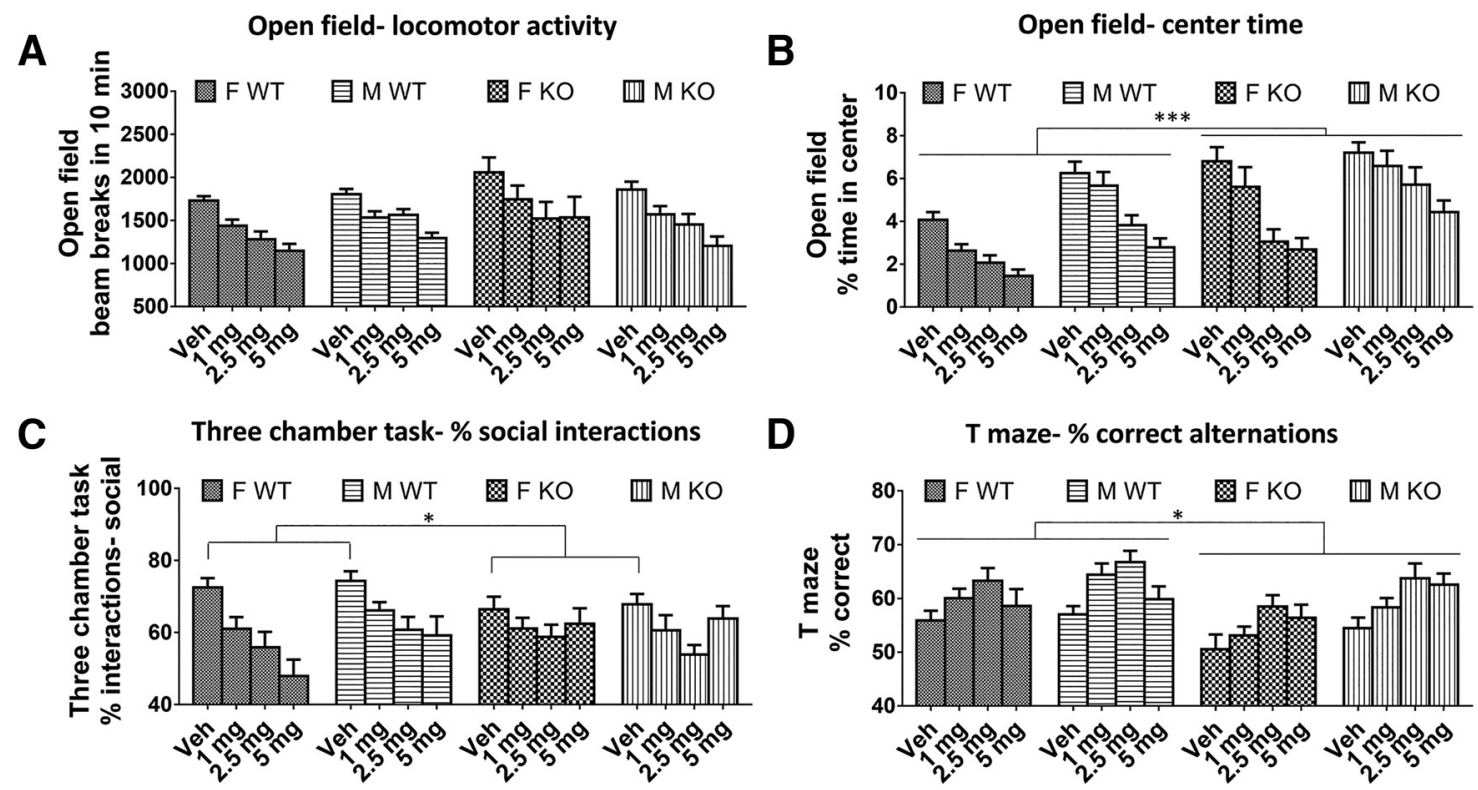

D T maze- \% correct alternations

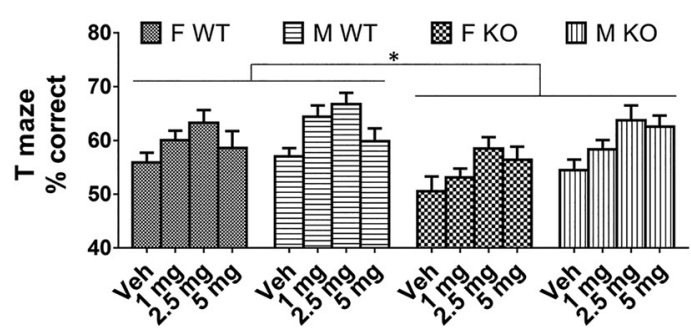

\section{Effects of Fmr1 KO and baclofen on behavior}

There was no difference between Fmr1 KO and WT mice in the number of beam breaks in 10 min with vehicle $(p=0.33)$ or during baclofen treatment $(p=0.28$; Fig. $3 A)$ in the open-field test. There was also no effect of sex (vehicle, $p=0.67$; baclofen, $p=0.77$ ). However, baclofen significantly decreased locomotor activity at all doses $\left[F_{(3,213)}=39.38, p<0.000001\right.$; Fig. $\left.3 A\right]$ in both genotypes and sexes (genotype $\times$ drug interaction, $p=0.52$; sex $\times$ drug interaction, $p=0.44$ ). For center time in the open field, there were significant main effects of genotype, sex,
B

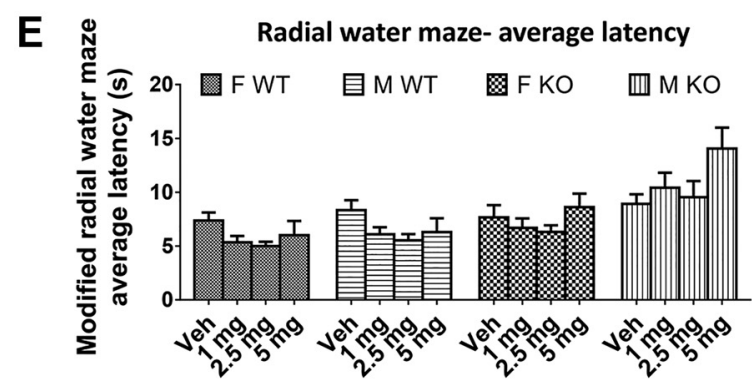


and baclofen treatment. Fmr1 KO mice spent a significantly greater proportion of the total time in the center than WT mice [vehicle: $F_{(1,73)}=17.70, p=0.00007$; baclofen: $F_{(1,71)}=12.49, p=0.0007$; Fig. 3B]. Males spent significantly more time in center than females [vehicle: $F_{(1,73)}=7.62, p<0.007$; baclofen: $F_{(1,71)}=28.68, p$ $=0.000001$; Fig. $3 B$ ]. Baclofen significantly decreased percentage center time $\left[F_{(3,213)}=50.11, p<0.000001\right.$; Fig. 3B], reversing the Fmr1 KO phenotype. This effect was similar in both genotypes (genotype $\times$ drug interaction, $p=0.51$ ) but was greater in females [sex $\times$ drug interaction, $F_{(3,213)}=3.23, p<0.05$; Fig. 3B].

Both Fmr1 KO and WT mice displayed a preference for interactions with the target mouse rather than the object (percentage social interactions $>50 \%$; Fig. $3 C$ ) during the three-chamber social interaction test. In the vehicle condition, social preference was decreased in $F m r 1 \mathrm{KO}$ mice compared with WT $\left[F_{(1,63)}=4.58, p=0.036\right.$; Fig. $\left.3 C\right]$. However, during baclofen treatment, this main effect was not significant $(p=0.87)$. There was no difference between males and females following either vehicle or baclofen (vehicle, $p=0.59$; baclofen, $p=0.28$ ). Baclofen significantly reduced sociability $\left[F_{(3,168)}=10.43, p=\right.$ 0.000002 ; Fig. $3 C$ ] to a similar extent in both genotypes (genotype $\times$ drug interaction, $p=0.11$ ) and sexes (sex $\times$ drug interaction, $p=0.70$ ).

Significant main effects of genotype, sex, and treatment were found on spontaneous alternation in the T-maze. Fmr1 KO mice had a significantly lower proportion of correct alternations than WT mice across baclofen doses $\left[F_{(1,70)}=5.84, p=0.018\right.$; Fig. $\left.3 D\right]$. This was less evident in the vehicle condition, which failed to reach significance $(p=0.057)$. Males made more correct alternations than females across baclofen doses $\left[F_{(1,70)}=9.16, \mathrm{p}=0.003\right]$, but this was not significant in the vehicle condition alone $(p=0.22)$. The working memory of all mice was significantly improved by baclofen $\left[F_{(3,210)}=10.71, p=\right.$ 0.000001 ; Fig. $3 D$ ], with no significant genotype $\times$ drug $(p$ $=0.10)$ or sex $\times$ drug $(p=0.84)$ interactions.

No effects of genotype or sex on latency to find the platform were observed on the radial water maze during test trials following vehicle (genotype, $p=0.67$; sex, $p=$ 0.17). However, across baclofen doses, significant main effects were found for genotype $\left[F_{(1,65)}=21.70, p=\right.$ 0.00002; Fig. 3E] and baclofen $\left[F_{(3,195)}=3.55, p=0.015\right.$; Fig. $3 E$, which were moderated by a genotype $\times$ drug interaction $\left[F_{(3,195)}=3.56, p=0.015\right]$. The main effect of genotype arose because there were contrasting effects of baclofen in WT and Fmr1 KO mice (Fig. 3E). In WT mice, baclofen at all doses decreased latency compared with vehicle (all at least $p<0.05$ ), whereas in Fmr1 KO mice, baclofen had no significant effect. Finally, across baclofen doses, latency to approach the platform was lower in female mice than male mice $\left[F_{(1,65)}=8.64, p=0.005\right]$.

\section{Relationship between baclofen gamma response and T-maze performance improvement}

To explore the plausibility of using EEG to predict behavioral treatment responsiveness, we investigated whether rescue of specific EEG abnormalities (baseline relative gamma power and evoked gamma power) at an individual level was associated with improvement in T-maze spontaneous alternation or open-field center time in Fmr1 KO and WT mice. These parameters were investigated at $2.5 \mathrm{mg} / \mathrm{kg}$ baclofen, the dose at which most consistent improvement of electrophysiological and behavioral deficits in Fmr1 KO mice was seen.

First, mice were grouped into baseline-relative gamma responders, whose baseline relative gamma power decreased with baclofen (in Fmr1 KO mice, this represented rescue of their abnormal baseline relative gamma power), and baseline relative gamma nonresponders, whose baseline relative gamma power increased with baclofen. There was no difference in $\Delta T$-maze performance (the change in percentage correct alternations after $2.5 \mathrm{mg} / \mathrm{kg}$ baclofen treatment compared with vehicle) between baseline relative gamma responders and nonresponders (all mice, $p=0.79$; WT only, $p=0.26$; Fmr1 KO only, $p=$ 0.51 ; Fig. $4 A-C)$. There was also no correlation of $\Delta$ baseline relative gamma power with $\Delta \mathrm{T}$-maze performance in WT or Fmr1 KO mice (WT only, $p=0.77$; Fmr1 $\mathrm{KO}$ only, $p=0.50$; Fig. $4 D$, E]. Second, mice were grouped into evoked gamma responders, whose evoked gamma power decreased with baclofen (in Fmr1 KO mice, this represented rescue of their deficit), and evoked gamma nonresponders, whose evoked gamma power increased with baclofen. In contrast to baseline gamma, there was a significant difference in postbaclofen T-maze performance between evoked gamma responders and nonresponders (Fig. 4F-H). These effects reached significance in all mice together $(t=3.16, \mathrm{df}=66, p=0.003$; Fig. $4 F)$ and in WT mice $(t=3.40, \mathrm{df}=33, p=0.002$; Fig. $4 G)$, but failed to do so in Fmr1 KO mice ( $t=1.35$, df $=31$, $p=0.19$; Fig. 4H). There was an inverse correlation between $\Delta$ evoked gamma power responses and $\Delta \mathrm{T}$-maze performance in all mice $(r=-0.33, p=0.006)$ and in WT mice $(r=-0.43, p=0.010$; Fig. $4 /)$ but not in Fmr1 KO mice $(r=-0.26, p=0.14$; Fig. 4J). Collectively, the animals that displayed the greatest baclofen-induced decrease in evoked gamma power showed the greatest improvement in T-maze performance. None of the above relationships were evident for open-field center time, in that there were no relationships between changes in baseline relative gamma power or evoked gamma power and open-field center time after $2.5 \mathrm{mg} / \mathrm{kg}$ baclofen (data not shown). Similarly, there were no significant correlations between changes in induced power and behavior after $2.5 \mathrm{mg} / \mathrm{kg}$ baclofen, or between changes in EEG measures and sociability (data not shown).

\section{Discussion}

After mixed results in human and animal studies, it is unclear whether baclofen and other pharmacotherapies targeting GABAergic neurotransmission can effectively treat the symptoms of FXS, particularly in the absence of biomarker-based strategies to target treatment to subsets of individuals. In this study, we present evidence that (a) sensory hypersensitivity occurs in Fmr1 $\mathrm{KO}$ mice, as indexed by increased evoked EEG gamma power, (b) baclofen normalizes this increased evoked EEG gamma 


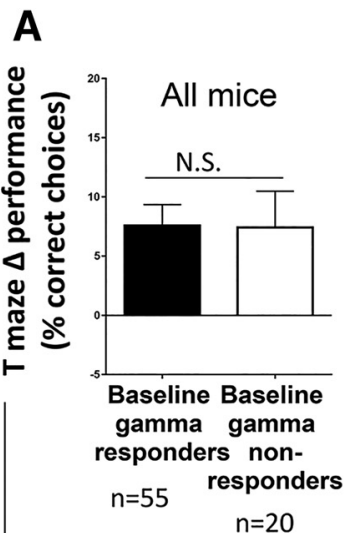

B

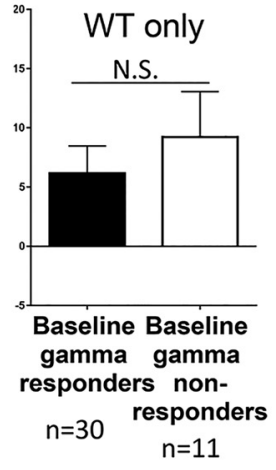

C

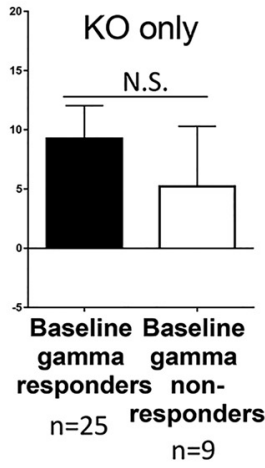

D

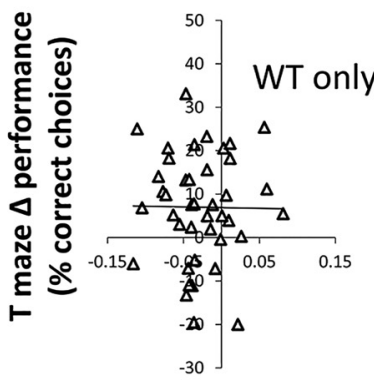

E

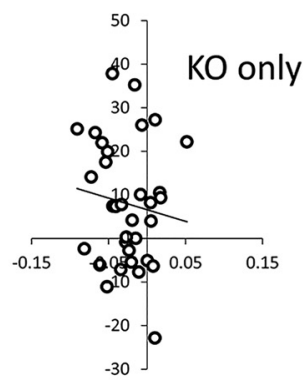

$\Delta$ Baseline relative gamma power after $2.5 \mathrm{mg} / \mathrm{kg}$ BAC

Relationships between baclofen-induced changes in baseline relative gamma oscillations and T maze performance

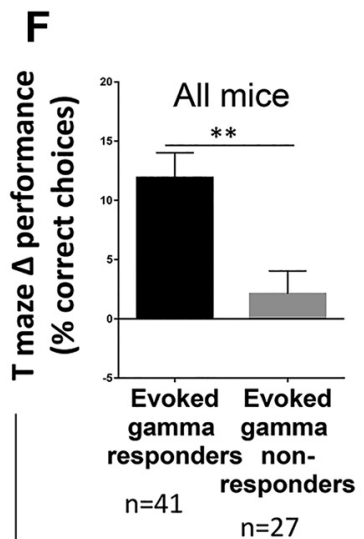

G

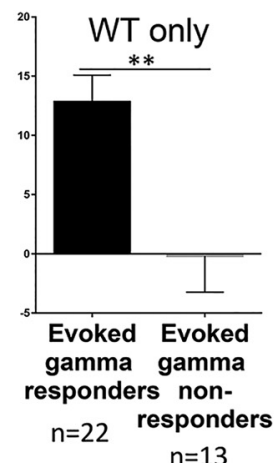

H

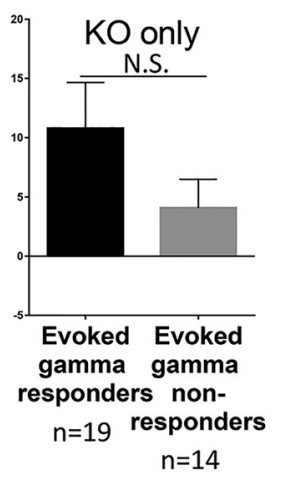

I

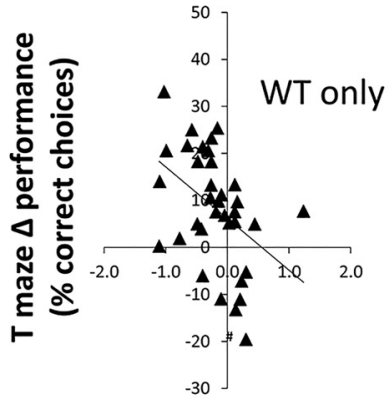

$\Delta$ Evoked gamma power after $2.5 \mathrm{mg} / \mathrm{kg}$ BAC

Relationships between baclofen-induced changes in evoked gamma oscillations and T maze performance

Figure 4. Relationships between changes in gamma power and improvements in T-maze performance after $2.5 \mathrm{mg} / \mathrm{kg}$ baclofen. $\boldsymbol{A}-\boldsymbol{C}$, Differences in T-maze performance between baseline relative gamma responders and baseline relative gamma nonresponders. $\boldsymbol{D}$, $\boldsymbol{E}$, Correlation of changes in relative baseline gamma power after $2.5 \mathrm{mg} / \mathrm{kg}$ baclofen with changes in T-maze performance in WT and Fmr1 KO mice. $\boldsymbol{F}-\boldsymbol{H}$, Differences in T-maze performance between evoked gamma responders and evoked gamma nonresponders. $\boldsymbol{I}, \boldsymbol{J}$, Correlation of changes in evoked gamma power after $2.5 \mathrm{mg} / \mathrm{kg}$ baclofen with changes in T-maze performance in WT mice and Fmr1 KO mice. BAC, baclofen, N.S., not significant. Error bars represent SEM. $* * p \leq 0.005$.

power and improves working memory (T-maze performance), and (c) at an individual level, normalization of evoked gamma oscillations was associated with improvement in working memory. Our study also suggests that some Fmr1 KO-related deficits, such as impaired sociability and episodic memory (radial water maze performance), may be impervious to rescue by baclofen. Overall, these findings indicate that racemic baclofen may have benefit for remediating sensory hypersensitivity and some cognitive deficits in FXS and suggest that evoked gamma oscillations may have potential utility for prediction of treatment responsiveness in some behavioral domains in the condition.

Increased evoked gamma power in Fmr1 KO mice is consistent with sensory hypersensitivity (Karaka and Baar, 1998), which is also seen in Fmr1 KO mice in the form of diminished ERP N1 habituation (Lovelace et al. 2016), neuronal hyperexcitability in the auditory cortex (Rotschafer and Razak, 2014), and increased prepulse inhibition (Chen and Toth, 2001). Increased sensitivity to sensory stimuli is also often observed in individuals with FXS (Kogan et al. 2004; Baranek et al. 2008). The diminution of evoked gamma power by racemic baclofen suggests that this agent may be particularly valuable in targeting the specific sensory hypersensitivity endophenotype in FXS.

A key finding of this study was that changes in evoked gamma power after $2.5 \mathrm{mg} / \mathrm{kg}$ baclofen were related to changes in T-maze performance, such that evoked gamma responders showed greater T-maze performance improvement than nonresponders. Baclofen-induced EEG changes, rather than predrug EEG measures, were analyzed because of their greater clinical potential. They enable a within-subject absolute criterion (evoked gamma decrease, yes/no) to be used to classify individual subjects and do not require normative reference data. In contrast, use of predrug evoked gamma power (analogous to vehicle treatment) would involve determination of 
normative ranges and collection of extensive reference data. Between genotype groups, there was a less strong relationship between baclofen-induced changes in evoked gamma oscillations and $\mathrm{T}$ maze performance in Fmr1 KO mice than in WT mice. This was expected, since baclofen targets a neurotransmitter system known to be dysregulated in Fmr1 $\mathrm{KO}$ mice. However, our findings suggest that further preclinical study of the possible link between evoked power changes and drug effectiveness for other pharmacotherapies is warranted given the potential benefit of this approach for individuals with FXS.

Increased baseline gamma power in FXS is a robust feature of the disorder, indicative of increased network noise and network hyperexcitability (Gandal et al. 2012a). It is observed in humans with FXS (Ethridge et al. 2016) and ASD (Orekhova et al. 2007; Wang et al. 2013). It is also seen in Fmr1 $\mathrm{KO}$ mice in vivo (in this study) and in vitro in thalamocortical slices from Fmr1 KO mice (Gibson et al. 2008). Racemic baclofen did not alter absolute power of baseline gamma oscillations in our study, in contrast to a prior study in which L-baclofen decreased absolute power of oscillations between 21 and $50 \mathrm{~Hz}$ (Marrosu et al. 2006). However, baclofen did decrease the relative power of baseline gamma oscillations as a proportion of total oscillatory activity. Further work is required to determine whether the importance of high-frequency oscillations lies in their absolute power or their power relative to other oscillatory activity. If absolute gamma power is more neurobiologically relevant, the failure of baclofen to rescue increased absolute baseline gamma power in Fmr1 KO mice may represent a limitation of this pharmacotherapy. If relative power of baseline oscillations has particular relevance, then investigation of other frequencies in Fmr1 KO mice is warranted, given that differences in relative upper alpha $(10-12 \mathrm{~Hz})$ and theta $(4-8 \mathrm{~Hz})$ power have been described in FXS (Van der Molen and Van der Molen, 2013). Nonetheless, as a potential translational biomarker, baseline gamma power may be a useful tool for designing and evaluating future therapeutic strategies for FXS.

The behavioral effects of baclofen reported here are partially consistent with prior studies. Improvement of spatial working memory by systemic baclofen has previously been reported in a similar T-maze task (Gandal et al. $2012 b$ ) and is in line with other cognition-enhancing properties of baclofen, including increased behavioral flexibility in rats (Beas et al. 2016). Because loss of FMRP results in abnormally increased open-field center exploration, it has been argued that the decrease in open-field center time by baclofen represents a beneficial, anxietynormalizing effect (Bhogal and Jongens, 2010). Interestingly, this effect was not seen with arbaclofen at 1.5 $\mathrm{mg} / \mathrm{kg}$ (Qin et al. 2015). Together with these beneficial effects of baclofen, there were indications of other effects that may not be therapeutically helpful. In particular, baclofen decreased sociability at all doses. This contrasts with two previous studies, one that found a beneficial effect of baclofen on sociability (Gandal et al. 2012b) and another that found no effect, but reported an increase in preference for social novelty (preference for novel over familiar stimulus mouse; Qin et al. 2015).

Although Fmr1 KO mice effectively mimic the loss of FMRP protein in FXS, they do not display a highly consistent behavioral phenotype. Some studies have reported spatial memory deficits in Fmr1 KO mice (Bakker et al. 1994; D'Hooge et al. 1997), but others have not (Peier et al. 2000; Leach et al. 2016). Deficits in working and episodic memory in Fmr1 KO mice are consistent with the clinical picture in FXS, in which intellectual disability is commonly seen. Decreased anxiety-like behavior and hyperactivity in the open field in Fmr1 KO mice are very often observed (e.g., Uutela et al. 2012; Dolan et al. 2013; Ding et al. 2014) but not always (Veeraragavan et al. 2011). A possible reason for this discrepancy is that the hyperactivity phenotype may diminish with repeated testing (Kramvis et al. 2013). Decreased social interactions by Fmr1 KO mice have been reported in free-interacting tests (Hébert et al. 2014; Oddi et al. 2015). However, when the three-chamber social interaction test is used, abnormalities are often not seen in sociability (Liu et al. 2011; Hébert et al. 2014), although other work has even shown increased sociability in Fmr1 KO mice (Gantois et al. 2013).

A possible reason for this inconsistency across studies with Fmr1 KO mice could involve stress, since Fmr1 KO mice appear to show enhanced corticosterone secretion in response to acute stress (Markham et al. 2006; Ghilan et al. 2015, but see Qin and Smith, 2008). The differential effects of acute stress on Fmr1 KO compared with controls may contribute to the Fmr1 KO behavioral phenotype in some tests, such as the T-maze or radial arm maze. Consequently, this phenotype may be particularly impacted by differences in the testing environment between studies. Furthermore, the animals in this study were individually housed after surgery and are likely to have experienced some longer-term stress associated with sustained social isolation that was not experienced by animals in other studies. Heightened adaptive or maladaptive responses of Fmr1 KO mice to chronic stress (Qin et al. 2011) may have further influenced genotype effects in this study. Future studies are warranted to clarify the role of stress in Fmr1-related pathology in mice and determine whether social isolation or socialization impacts the expression of functional deficits in humans with FXS.

Sex $\times$ genotype interactions were observed for absolute and relative baseline gamma power, with increased baseline gamma power seen in male but not female Fmr1 $\mathrm{KO}$ mice. This is consistent with the increased severity of FXS in human males (Crawford et al. 2001). However, unlike in humans, sex differences in the expression of FXS-related phenotypes in this study are unlikely to relate to variable penetrance of the genetic manipulation/mutation, since this study used complete knockout of Fmr1 for both sexes. Instead, they are more likely to reflect the interaction of FMRP signaling with sex differences in other pathways.

Several lines of evidence have identified GABAergic interneurons as the primary source of gamma oscillations in the brain (Traub et al. 1996; Bartos et al. 2007). Mice 
with the NMDA subunit 1 receptor selectively removed from parvalbumin-expressing GABAergic interneurons show a similar EEG profile to Fmr1 KO mice, including increased basal gamma EEG, and display several autismlike behavioral changes (Carlén et al. 2012; Saunders et al. 2013; Billingslea et al. 2014). Increased gamma oscillations are thought to be due to a loss of the normal inhibitory control typically exerted by GABAergic cells, leading toward a loss of excitatory/inhibitory balance. This suggests that the primary pathology underlying the EEG abnormalities reported here in Fmr1 KO mice may reflect a loss of GABA integrity. Baclofen stimulates GABA-B receptors both presynaptically, resulting in decreased glutamate release (Isaacson and Hille, 1997), and postsynaptically, resulting in decreased excitability due to voltage gated potassium channel activation (Lüscher et al. 1997). GABA-B agonism by baclofen may compensate for GABAergic pathology in Fmr1 KO mice, such as decreased GABA receptor abundance (Gantois et al. 2006; Adusei et al. 2010). Additionally, arbaclofen has also been shown to decrease protein synthesis (Henderson et al. 2012; Qin et al. 2015), potentially counteracting excess protein production due to FMRP loss (Darnell et al. 2011).

This study had a number of limitations. A within-subject design was used, enabling assessment of the acute effects of baclofen across multiple domains. However, later behavioral tests (such as social interaction and radial water maze) may have been influenced by lingering effects of prior baclofen exposure despite the 4 to $5 \mathrm{~d}$ washout. In the open-field test and other tests, habituation to the test environment may also have modified the behavioral measures and confounded the effects of baclofen. Furthermore, findings at the highest baclofen dose $(5 \mathrm{mg} / \mathrm{kg})$ may have been influenced by the sedative effect of the drug, accounting for its diminished efficacy in T-maze and water maze tests at that dose. Ultimately, the value of the findings described in this study will be determined by the extent of their translatability and predictive validity for individuals with FXS.

\section{References}

Adusei DC, Pacey LK, Chen D, Hampson DR (2010) Early developmental alterations in GABAergic protein expression in fragile $X$ knockout mice. Neuropharmacology 59:167-171. CrossRef Medline

Bailey DB, Raspa M, Olmsted M, Holiday DB (2008) Co-occurring conditions associated with FMR1 gene variations: findings from a national parent survey. Am J Med Genet Part A 146:2060-2069. CrossRef

Bailey DB, Jr., Raspa M, Bishop E, Olmsted M, Mallya UG, BerryKravis E (2012) Medication utilization for targeted symptoms in children and adults with fragile $X$ syndrome: US survey. J Dev Behav Pediatr 33:62-69. CrossRef Medline

Bakker CE, Verheij C, Willemsen R, Vanderhelm R, Oerlemans F, Vermey M, Bygrave A, Hoogeveen AT, Oostra BA, Reyniers E, Deboulle K, Dhooge R, Cras P, Vanvelzen D, Nagels G, Martin JJ, Dedeyn PP, Darby JK, Willems PJ (1994) Fmr1 knockout mice: a model to study fragile $X$ mental retardation. Cell 78:23-33.

Baranek GT, Roberts JE, David FJ, Sideris J, Mirrett PL, Hatton DD, Bailey DB Jr. (2008) Developmental trajectories and correlates of sensory processing in young boys with fragile $X$ syndrome. Phys Occup Ther Pediatr 28:79-98. Medline
Bartos M, Vida I, Jonas P (2007) Synaptic mechanisms of synchronized gamma oscillations in inhibitory interneuron networks. Nat Rev Neurosci 8:45-56. CrossRef Medline

Beas BS, Setlow B, Bizon JL (2016) Effects of acute administration of the $\mathrm{GABA}(\mathrm{B})$ receptor agonist baclofen on behavioral flexibility in rats. Psychopharmacology (Berl) 233:2787-2797. CrossRef Medline

Berry-Kravis EM, Hessl D, Rathmell B, Zarevics P, Cherubini M, Walton-Bowen K, Mu Y, Nguyen DV, Gonzalez-Heydrich J, Wang PP, Carpenter RL, Bear MF, Hagerman RJ (2012) Effects of STX209 (arbaclofen) on neurobehavioral function in children and adults with fragile $X$ syndrome: a randomized, controlled, phase 2 trial. Sci Transl Med 4:152ra127. CrossRef Medline

Bhogal B, Jongens TA (2010) Fragile X syndrome and model organisms: identifying potential routes of therapeutic intervention. Dis Model Mech 3:693-700. CrossRef Medline

Billingslea EN, Tatard-Leitman VM, Anguiano J, Jutzeler CR, Suh J, Saunders JA, Morita S, Featherstone RE, Ortinski PI, Gandal MJ, Lin R, Liang Y, Gur RE, Carlson GC, Hahn CG, Siegel SJ (2014) Parvalbumin cell ablation of NMDA-R1 causes increased resting network excitability with associated social and self-care deficits. Neuropsychopharmacology 39:1603-1613. CrossRef Medline

Buzsáki G, Wang XJ (2012) Mechanisms of gamma oscillations. Annu Rev Neurosci 35:203-225. CrossRef Medline

Carlén M, Meletis K, Siegle JH, Cardin JA, Futai K, Vierling-Claassen D, Rühlmann C, Jones SR, Deisseroth K, Sheng M, Moore Cl, Tsai LH (2012) A critical role for NMDA receptors in parvalbumin interneurons for gamma rhythm induction and behavior. Mol Psychiatry 17:537-548. CrossRef Medline

Castrén M, Pääkkönen A, Tarkka IM, Ryynänen M, Partanen J (2003) Augmentation of auditory $\mathrm{N} 1$ in children with fragile $\mathrm{X}$ syndrome. Brain Topogr 15:165-171. Medline

Chen L, Toth M (2001) Fragile X mice develop sensory hyperreactivity to auditory stimuli. Neuroscience 103:1043-1050. Medline

Crawford DC, Acuña JM, Sherman SL (2001) FMR1 and the fragile X syndrome: human genome epidemiology review. Genet Med 3:359-371. CrossRef Medline

D'Hooge R, Nagels G, Franck F, Bakker CE, Reyniers E, Storm K, Kooy RF, Oostra BA, Willems PJ, DeDeyn PP (1997) Mildly impaired water maze performance in male Fmr1 knockout mice. Neuroscience 76:367-376. Medline

Darnell JC, Van Driesche SJ, Zhang C, Hung KY, Mele A, Fraser CE, Stone EF, Chen C, Fak JJ, Chi SW, Licatalosi DD, Richter JD, Darnell RB (2011) FMRP stalls ribosomal translocation on mRNAs linked to synaptic function and autism. Cell 146:247-261. CrossRef Medline

Delorme A, Makeig S (2004) EEGLAB: an open source toolbox for analysis of single-trial EEG dynamics including independent component analysis. J Neurosci Methods 134:9-21. CrossRef Medline

Ding Q, Sethna F, Wang H (2014) Behavioral analysis of male and female Fmr1 knockout mice on C57BL/6 background. Behav Brain Res 271:72-78. CrossRef Medline

Dolan BM, Duron SG, Campbell DA, Vollrath B, Shankaranarayana Rao BS, Ko HY, Lin GG, Govindarajan A, Choi SY, Tonegawa S (2013) Rescue of fragile X syndrome phenotypes in Fmr1 KO mice by the small-molecule PAK inhibitor FRAX486. Proc Natl Acad Sci U S A 110:5671-5676. CrossRef Medline

Ehrlichman RS, Luminais SN, White SL, Rudnick ND, Ma N, Dow HC, Kreibich AS, Abel T, Brodkin ES, Hahn CG, Siegel SJ (2009) Neuregulin 1 transgenic mice display reduced mismatch negativity, contextual fear conditioning and social interactions. Brain Res 1294:116-127. CrossRef Medline

Ethridge LE, White SP, Mosconi MW, Wang J, Byerly MJ, Sweeney JA (2016) Reduced habituation of auditory evoked potentials indicate cortical hyper-excitability in fragile X syndrome. Transl Psychiatr 6:e787. CrossRef Medline

Featherstone RE, Shin R, Kogan JH, Liang YL, Matsumoto M, Siegel SJ (2015) Mice with subtle reduction of NMDA NR1 receptor subunit expression have a selective decrease in mismatch nega- 
tivity: implications for schizophrenia prodromal population. Neurobiol Dis 73:289-295. CrossRef

Frankland PW, Wang Y, Rosner B, Shimizu T, Balleine BW, Dykens EM, Ornitz EM, Silva AJ (2004) Sensorimotor gating abnormalities in young males with fragile $X$ syndrome and Fmr1-knockout mice. Mol Psychiatry 9:417-425. CrossRef Medline

Gandal MJ, Edgar JC, Klook K, Siegel SJ (2012a) Gamma synchrony: towards a translational biomarker for the treatment-resistant symptoms of schizophrenia. Neuropharmacology 62:1504-1518.

Gandal MJ, Sisti J, Klook K, Ortinski PI, Leitman V, Liang Y, Thieu T, Anderson R, Pierce RC, Jonak G, Gur RE, Carlson G, Siegel SJ (2012b) GABAB-mediated rescue of altered excitatory-inhibitory balance, gamma synchrony and behavioral deficits following constitutive NMDAR-hypofunction. Transl Psychiatry 2:e142.

Gantois I, Vandesompele J, Speleman F, Reyniers E, D'Hooge R, Severijnen LA, Willemsen R, Tassone F, Kooy RF (2006) Expression profiling suggests underexpression of the $G A B A(A)$ receptor subunit delta in the fragile $X$ knockout mouse model. Neurobiol Dis 21:346-357. CrossRef Medline

Gantois I, Pop AS, de Esch CE, Buijsen RA, Pooters T, GomezMancilla B, Gasparini F, Oostra BA, D'Hooge R, Willemsen R (2013) Chronic administration of AFQ056/Mavoglurant restores social behaviour in Fmr1 knockout mice. Behav Brain Res 239:7279. CrossRef Medline

Ghilan M, Hryciw BN, Brocardo PS, Bostrom CA, Gil-Mohapel J, Christie BR (2015) Enhanced corticosteroid signaling alters synaptic plasticity in the dentate gyrus in mice lacking the fragile $X$ mental retardation protein. Neurobiol Dis 77:26-34. CrossRef Medline

Gibson JR, Bartley AF, Hays SA, Huber KM (2008) Imbalance of neocortical excitation and inhibition and altered UP states reflect network hyperexcitability in the mouse model of fragile $X$ syndrome. J Neurophysiol 100:2615-2626. CrossRef Medline

Gonçalves JT, Anstey JE, Golshani P, Portera-Cailliau C (2013) Circuit level defects in the developing neocortex of Fragile $\mathrm{X}$ mice. Nat Neurosci 16:903-909. CrossRef Medline

Healy A, Rush R, Ocain T (2011) Fragile X syndrome: an update on developing treatment modalities. ACS Chem Neurosci 2:402-410. CrossRef Medline

Hébert B, Pietropaolo S, Même S, Laudier B, Laugeray A, Doisne N, Quartier A, Lefeuvre S, Got L, Cahard D, Laumonnier F, Crusio WE, Pichon J, Menuet A, Perche O, Briault S (2014) Rescue of fragile X syndrome phenotypes in $\mathrm{Fmr} 1 \mathrm{KO}$ mice by a BKCa channel opener molecule. Orphanet J Rare Dis 9:124. CrossRef Medline

Henderson C, Wijetunge L, Kinoshita MN, Shumway M, Hammond RS, Postma FR, Brynczka C, Rush R, Thomas A, Paylor R, Warren ST, Vanderklish PW, Kind PC, Carpenter RL, Bear MF, Healy AM (2012) Reversal of disease-related pathologies in the fragile $X$ mouse model by selective activation of GABAB receptors with arbaclofen. Sci Transl Med 4:152ra128. CrossRef Medline

Isaacson JS, Hille B (1997) GABA(B)-mediated presynaptic inhibition of excitatory transmission and synaptic vesicle dynamics in cultured hippocampal neurons. Neuron 18:143-152. Medline

Karaka S, Baar E (1998) Early gamma response is sensory in origin: a conclusion based on cross-comparison of results from multiple experimental paradigms. Int J Psychophysiol 31:13-31. CrossRef

Kogan CS, Bertone A, Cornish K, Boutet I, Der Kaloustian VM, Andermann E, Faubert J, Chaudhuri A (2004) Integrative cortical dysfunction and pervasive motion perception deficit in fragile $X$ syndrome. Neurology 63:1634-1639. Medline

Kramvis I, Mansvelder HD, Loos M, Meredith R (2013) Hyperactivity, perseveration and increased responding during attentional rule acquisition in the fragile $\mathrm{X}$ mouse model. Front Behav Neurosci 7:172. CrossRef Medline

Leach PT, Hayes J, Pride M, Silverman JL, Crawley JN (2016) Normal performance of Fmr1 mice on a touchscreen delayed nonmatching to position working memory task. eNeuro 3:ENEURO.014315.2016. CrossRef
Liu ZH, Chuang DM, Smith CB (2011) Lithium ameliorates phenotypic deficits in a mouse model of fragile $X$ syndrome. Int $J$ Neuropsychopharmacol 14:618-630. CrossRef

Lovelace JW, Wen TH, Reinhard S, Hsu MS, Sidhu H, Ethell IM, Binder DK, Razak KA (2016) Matrix metalloproteinase-9 deletion rescues auditory evoked potential habituation deficit in a mouse model of fragile X syndrome. Neurobiol Dis 89:126-135. CrossRef

Lozano R, Hare EB, Hagerman RJ (2014) Modulation of the GABAergic pathway for the treatment of fragile $X$ syndrome. Neuropsychiatr Dis Treat 10:1769-1779. CrossRef Medline

Lüscher C, Jan LY, Stoffel M, Malenka RC, Nicoll RA (1997) G protein-coupled inwardly rectifying $\mathrm{K}+$ channels (GIRKs) mediate postsynaptic but not presynaptic transmitter actions in hippocampal neurons. Neuron 19:687-695. CrossRef

Markham JA, Beckel-Mitchener AC, Estrada CM, Greenough WT (2006) Corticosterone response to acute stress in a mouse model of fragile $X$ syndrome. Psychoneuroendocrinology 31:781-785. CrossRef Medline

Marrosu F, Santoni F, Fa M, Puligheddu M, Barberini L, Genugu F, Frau R, Manunta M, Mereu G (2006) Beta and gamma range EEG power-spectrum correlation with spiking discharges in DBA/2J mice absence model: role of GABA receptors. Epilepsia 47:489494. CrossRef Medline

Oddi D, Subashi E, Middei S, Bellocchio L, Lemaire-Mayo V, Guzmán M, Crusio WE, D'Amato FR, Pietropaolo S (2015) Early social enrichment rescues adult behavioral and brain abnormalities in a mouse model of fragile $X$ syndrome. Neuropsychopharmacology 40:1113-1122. CrossRef

Orekhova EV, Stroganova TA, Nygren G, Tsetlin MM, Posikera IN, Gillberg C, Elam M (2007) Excess of high frequency electroencephalogram oscillations in boys with autism. Biol Psychiatr 62: 1022-1029. CrossRef Medline

Pacey LK, Heximer SP, Hampson DR (2009) Increased GABA(B) receptor-mediated signaling reduces the susceptibility of fragile $X$ knockout mice to audiogenic seizures. Mol Pharmacol 76:18-24. CrossRef Medline

Paluszkiewicz SM, Olmos-Serrano JL, Corbin JG, Huntsman MM (2011) Impaired inhibitory control of cortical synchronization in fragile X syndrome. J Neurophysiol 106:2264-2272. CrossRef Medline

Peier AM, Mcllwain KL, Kenneson A, Warren ST, Paylor R, Nelson DL (2000) (Over)correction of FMR1 deficiency with YAC transgenics: behavioral and physical features. Hum Mol Genet 9:1145-1159. Medline

Qin M, Smith CB (2008) Unaltered hormonal response to stress in a mouse model of fragile $X$ syndrome. Psychoneuroendocrinology 33:883-889. CrossRef Medline

Qin M, Xia Z, Huang T, Smith CB (2011) Effects of chronic immobilization stress on anxiety-like behavior and basolateral amygdala morphology in Fmr1 knockout mice. Neuroscience 194:282-290. CrossRef Medline

Qin M, Huang T, Kader M, Krych L, Xia Z, Burlin T, Zeidler Z, Zhao T, Smith CB (2015) R-baclofen reverses a social behavior deficit and elevated protein synthesis in a mouse model of fragile $X$ syndrome. Int J Neuropsychopharmacol 18:pii:pyv034. CrossRef

Radwan B, Dvorak D, Fenton AA (2016) Impaired cognitive discrimination and discoordination of coupled theta-gamma oscillations in Fmr1 knockout mice. Neurobiol Dis 88:125-138. CrossRef Medline Rotschafer SE, Razak KA (2014) Auditory processing in fragile $X$ syndrome. Front Cell Neurosci 8:19. CrossRef Medline

Salinas E, Sejnowski TJ (2001) Correlated neuronal activity and the flow of neural information. Nat Rev Neurosci 2:539-550. CrossRef Medline

Sankoorikal GM, Kaercher KA, Boon CJ, Lee JK, Brodkin ES (2006) A mouse model system for genetic analysis of sociability: C57BL/6J versus BALB/cJ inbred mouse strains. Biol Psychiatry 59:415-423. CrossRef Medline

Saunders JA, Tatard-Leitman VM, Suh J, Billingslea EN, Roberts TP, Siegel SJ (2013) Knockout of NMDA receptors in parvalbumin 
interneurons recreates autism-like phenotypes. Autism Res 6:6977. CrossRef Medline

Silverman JL, Pride MC, Hayes JE, Puhger KR, Butler-Struben HM, Baker S, Crawley JN (2015) GABAB receptor agonist R-baclofen reverses social deficits and reduces repetitive behavior in two mouse models of autism. Neuropsychopharmacology 40:22282239. CrossRef Medline

Sinclair D, Oranje B, Razak KA, Siegel SJ, Schmid S (2016) Sensory processing in autism spectrum disorders and fragile $X$ syndrome: from the clinic to animal models. Neurosci Biobehav Rev pii: S0149-7634(15)30318-3.

St Clair DM, Blackwood DH, Oliver CJ, Dickens P (1987) P3 abnormality in fragile $X$ syndrome. Biol Psychiatry 22:303-312. Medline

Tatard-Leitman VM, Jutzeler CR, Suh J, Saunders JA, Billingslea EN, Morita S, White R, Featherstone RE, Ray R, Ortinski PI, Banerjee A, Gandal MJ, Lin R, Alexandrescu A, Liang Y, Gur RE, BorgmannWinter KE, Carlson GC, Hahn C-G, Siegel SJ (2015) Pyramidal cell selective ablation of $\mathrm{N}$-methyl-D-aspartate receptor 1 causes increase in cellular and network excitability. Biol Psychiatr 77:556568. CrossRef Medline

Traub RD, Whittington MA, Colling SB, Buzsáki G, Jefferys JG (1996) Analysis of gamma rhythms in the rat hippocampus in vitro and in vivo. J Physiol 493(Pt 2):471-484. CrossRef

Turner G, Webb T, Wake S, Robinson H (1996) Prevalence of fragile X syndrome. Am J Med Genet 64:196-197. CrossRef Medline

Uutela M, Lindholm J, Louhivuori V, Wei H, Louhivuori LM, Pertovaara A, Akerman K, Castrén E, Castrén ML (2012) Reduction of
BDNF expression in Fmr1 knockout mice worsens cognitive deficits but improves hyperactivity and sensorimotor deficits. Gen Brain Behav 11:513-523. CrossRef Medline

Van der Molen MJ, Van der Molen MW (2013) Reduced alpha and exaggerated theta power during the resting-state EEG in fragile $X$ syndrome. Biol Psychol 92:216-219. CrossRef Medline

Van der Molen MJ, Van der Molen MW, Ridderinkhof KR, Hamel BC, Curfs LM, Ramakers GJ (2012a) Auditory change detection in fragile $X$ syndrome males: a brain potential study. Clin Neurophysiol 123:1309-1318.

Van der Molen MJ, Van der Molen MW, Ridderinkhof KR, Hamel BC, Curfs LM, Ramakers GJ (2012b) Auditory and visual cortical activity during selective attention in fragile $X$ syndrome: a cascade of processing deficiencies. Clin Neurophysiol 123:720-729.

Veeraragavan S, Bui N, Perkins JR, Yuva-Paylor LA, Carpenter RL, Paylor R (2011) Modulation of behavioral phenotypes by a muscarinic $\mathrm{M} 1$ antagonist in a mouse model of fragile $\mathrm{X}$ syndrome. Psychopharmacology 217:143-151. CrossRef

Verkerk AJ, Pieretti M, Sutcliffe JS, Fu YH, Kuhl DP, Pizzuti A, Reiner O, Richards S, Victoria MF, Zhang FP, et al. (1991) Identification of a gene (FMR-1) containing a CGG repeat coincident with a breakpoint cluster region exhibiting length variation in fragile $X$ syndrome. Cell 65:905-914. Medline

Wang J, Barstein J, Ethridge LE, Mosconi MW, Takarae Y, Sweeney JA (2013) Resting state EEG abnormalities in autism spectrum disorders. J Neurodev Disord 5:24. CrossRef Medline 